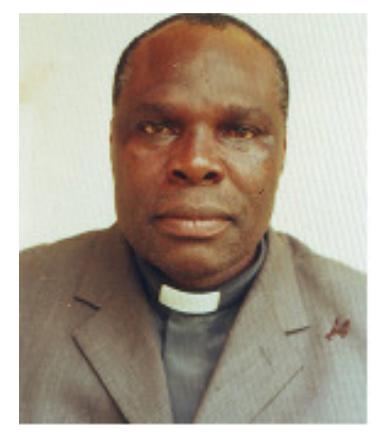

\title{
TRIBUTE TO AN ACADEMIC LUMINARY Canon Engr. Prof. Nkemakonam Nwolisa Osadebe, 1955 - 2015
}

The news of the death of Canon Engr. Prof. Nkemakonam Nwolisa Osadebe on Friday 23rd October, 2015 was a great shock to us. It was as if the activities in the Faculty of Engineering, University of Nigeria, Nsukka was brought to a standstill by the passing away of such an academic luminary known nationally and internationally.

For over 25 years he laboured in the Department of Civil Engineering, the Faculty and the University of Nigeria, Nsukka in different capacities after transferring his service from the Enugu State University of Science and Technology, Enugu.

As a professor of Civil Engineering since October 01 1998, he contributed immensely to the growth of the University as the chairman or member of several task forces and committees. He was the Head, Department of Civil Engineering, 1993 to 1996; Associate Dean, Faculty of Engineering, 1998 to 1999; Dean, Faculty of Engineering, 2008 to 2010; and so on.

He was a lecturer in the Department of Civil Engineering where I lecture, served as his immediate successor as the Dean of the Faculty of Engineering. He was once the Director of National Centre for Equipment Maintenance and Development (NCEMD) where I am presently the director. In these places and positions I had always sought for his advice on several issues. I will ever cherish his encouraging words.

I have noticed three types of colleagues in my sojourn as a lecturer. Some will make relentless efforts to correct injustice only when their own rights are trampled upon. Others labour diligently but in silence hoping that things will work out better while a few will fight against injustice, selflessly at all cost, no matter who the victim is. Prof. Osadebe belonged to this last group. He stood firmly for the truth. His type is very rare. He was an advocate for the poor, the downtrodden and those whose academic rights were denied. I am yet to see a man who stood out eminently for the truth and against injustice meted out on the powerless even when he is not in any way related to the person(s) that are being victimized.

As a world-wide acclaimed professor of structural engineering, he published numerous research papers and graduated several higher degree students. Many of his students are now professors and heads of very distinguished academic and professional institutions.

Prof. Osadebe served meritoriously in the Editorial Board of the Nigerian Journal of Technology for several years while I was the editor and currently the editor-in-chief. He always gave me maximum support whenever I needed it, especially during the difficult transition years.

On behalf of the members of the editorial board of the Nigerian Journal of Technology, I wish to extend our condolences to his wife, children, and fellow academics. May God grant us the fortitude to bear this irreparable loss. May we take solace in the fact that he is resting in the bosom of our loving Father.

\section{Engr. Prof. Jonah C. Agunwamba Editor-in-Chief, NIJOTECH jonah.agunwamba@unn.edu.ng}

